\title{
MENINGKATKAN HASIL BELAJAR MATEMATIKA SISWA MELALUI PENERAPAN CONTEXTUAL TEACHING AND LEARNING (CTL)
}

\author{
Hariani $\operatorname{Arief}^{1}$ Saman $^{2}$ \\ Universitas Cokroaminoto Palopo ${ }^{1,}$ Universitas Muhammadiyah Palopo ${ }^{2}$ \\ hariani_arief@yahoo.com ${ }^{I}$,Saman@Umpalopo.ac.id
}

\begin{abstract}
Abstrak
Tujuan penelitian ini adalah untuk meningkatkan hasil belajar siswa terhadap pembelajaran matematika melalui penerapan CTL pada kelas IV SDN 20 Battang. Bentuk penelitian ini adalah penelitian tindakan kelas yang terdiri dari dua siklus. Teknik pengumpulan data menggunakan observasi, angket dan test. Subyek penelitian adalah siswa kela IV SDN 20 Battang. Teknik analisis data menggunakan model interaktif yang terdiri dari tiga komponen analisis yaitu reduksi data, sajian data dan penarikan kesimpulan. Berdasarkan hasil penelitian dapat disimpulkan, 1) meningkatnya hasil belajar matematika siswa sebelum dilakukan tindakan dikategorikan sangat rendah rendah dan setelah penerapan pendekatan CTL mencapai kategori sangat tinggi, 2) setelah pendekatan CTL diterapkan maka hasil belajar matematika siswa pada kelas IV SDN 20 Battang meningkat.

Kata kunci: Hasil Belajar, Contextual Teaching and Learning (CTL).
\end{abstract}

\section{A. Pendahuluan}

Manusia dalam melaksanakan fungsi-fungsi kehidupan tidak lepas dan tidak akan lepas dari pendidikan, karena pendidikan berfungsi untuk meningkatkan kualitas manusia baik individu maupun kelompok. Pendidikan dilihat dari sudut pandang tertentu akan berbeda pengertiannya akan tetapi maksudnya tertuju pada peningkatan kualitas sumber daya manusia. Untuk meningkatkan kualitas sumber daya manusia tersebut maka setiap orang harus menempuh pendidikan, baik formal maupun nonformal. Sekolah dasar sebagai salah satu bentuk satuan pendidikan dasar pada jalur pendidikan formal. Dari isi kurikulum pada sekolah dasar, matematika merupakan salah satu mata pelajaran yang diberikan di sekolah dasar.

Berdasarkan buku KTSP 2006 dituliskan bahwa pembelajaran matematika hendaknya dimulai dengan pengenalan masalah yang sesuai dengan situasi, dengan mengajukan masalah kontekstual, peserta didik secara bertahap dibimbing untuk menguasai konsep matematika. 
Fakta di lapangan, diperoleh bahwa proses pembelajaran sekolah dasar masih kurang variatif dan inovatif serta kurang kontekstual dalam menentukan model pembelajaran yang tepat dalam materi pembelajaran matematika di SD. Akibatnya adalah pembelajaran matematika terasa jenuh dan siswa kurang memahami materi pembelajaran. Selain itu pembelajaran selama ini dilakukan masih bersifat konvensional, pembelajaran antara guru dan siswa tidak berjalan interaktif. Penggunaan media dalam proses pembelajaran masih jarang dilakukan, siswa hampir pasif dalam proses pembelajaran. Hal ini terlihat dari hanya 2 dari 14 siswa yang berani untuk bertanya ataupun menjawab pertanyaan dari guru, sehingga pembelajaran matematika di kelas dirasa kurang bermakna. Hasil Ujian Tengah Semesterpun tidak memuaskan dimana nilai rata-rata siswa masih dibawah nilai KKM (68) yaitu 58,39.

Membelajarkan matematika di sekolah berarti mengajak siswa untuk memahami Matematika sebagai ilmu pengetahuan yang akan berguna bagi siswa untuk mempelajari ilmu pengetahuan yang lain. Belajar matematika akan menjadi kegiatan yang menarik apabila siswa merasakan nilai kemanfaatan Matematika tersebut dalam kehidupan sehari-hari. Apabila siswa merasakan kemanfaatan dari mata pelajaran Matematika, siswa akan mempelajari Matematika sebagai sebuah kebutuhan yang harus dipenuhi.

Mengatasi permasalahan rendahnya kualitas pendidikan Indonesia dan rendahnya manfaat output pendidikan, pandangan untuk membelajarkan Matematika dengan cara melihat nilai kemanfaatan Matematika dalam kehidupan sehari-hari mulai ditekankan. Banyak siswa belum merasakan manfaat hasil belajar Matematika untuk dikaitkan dalam mengatasi permasalahan hidup sehari-hari. Keadaan ini menjadikan minat belajar siswa menjadi rendah. Berdasarkan pandangan bahwa membelajarkan Matematika perlu melihat kontekstual Matematika dengan kehidupan nyata, diharapkan siswa memperoleh materi pembelajaran yang lebih bermakna. Kebermaknaan materi pelajaran Matematika diharapkan dapat membawa siswa pada pemahaman dan pendalaman materi Matematika yang baik.

Pendekatan pembelajaran yang digunakan oleh guru mempunyai peranan penting dalam keberhasilan pendidikan. Penggunaaan pendekatan pembelajaran 
yang tepat akan menentukan keefektifan dan keefisienan dalam proses belajar mengajar. Guru harus senantiasa mampu memilih dan menerapkan pendekatan pembelajaran yang tepat sesuai dengan pokok bahasan yang diajarkan.

Apabila dalam membelajarkan Matematika di sekolah, guru berupaya menghubungkannya dengan kehidupan nyata, ada beberapa keuntungan antara lain: Pertama, siswa akan memahami bahwa Matematika sangat penting untuk membantu memecahkan persoalan sehari-hari. Kedua, siswa tidak akan terbawa pada konsep yang terlalu abstrak, tetapi akan dibawa pada persoalan yang mudah dibayangkan, dipikirkan oleh siswa. Hal ini akan mempermudah siswa dalam memahami pelajaran Matematika. Ketiga, pendekatan guru dalam membelajarkan Matematika akan lebih variasi. Pada akhirnya, proses pembelajaran yang tidak bervariasi, yang akan menambah keasyikan siswa dalam menikmati proses belajar Matematika.

Depdiknas (2003:1) menyatakan bahwa "Pendekatan kontekstual (Contextual Teaching and Learning)merupakan konsep belajar yang membantu guru mengaitkan antara materi yang diajarkannya dengan situasi dunia nyata siswa dan mendorong siswa membuat hubungan antara pengetahuan yang dimilikinya dengan penerapannya dalam kehidupan mereka sebagai anggota keluarga dan masyarakat." Dengan konsep itu, hasil pembelajaran diharapkan lebih bermakna bagi siswa. Proses pembelajaran berlangsung alamiah dalam bentuk kegiatan siswa bekerja dan mengalami, bukan transfer pengetahuan dari guru ke siswa.

Pembelajaran kontekstual adalah sebuah sistem yang merangsang otak untuk menyusun pola-pola yang mewujudkan makna. Otak terus menerus mencari makna dan menyimpan hal-hal bermakna. Pembelajaran kontekstual mengajak para siswa membuat hubungan-hubungan yang mengungkapkan makna, sehingga pembelajaran kontekstual memiliki potensi untuk membuat para siswa berminat belajar (Jhonson 2009:35).

Ada beberapa alasan tentang perlunya belajar menguasai matematika bahwa: Matematika perlu diajarkan kepada siswa karena, 1) selalu digunakan dalam kehidupan sehari-hari, 2) semua bidang studi memerlukan keterampilan yang sesuai, 3) merupakan sarana komunikasi yang kuat, jelas dan singkat, 4) dapat digunakan dalam, 5) meningkatkan kemampuan berfikir logis, ketelitian dan 
kesadaran keruangan, 6) memberikan kepuasaan terhadap usaha memecahkan masalah yang mendatang.

Berdasarkan latar belakang masalah tersebut, maka akan digunakan model pendekatan kontekstual dalam Penelitian Tindakan Kelas yang akan dilaksanakan dengan judul “ Meningkatkan Hasil Belajar Matematika Siswa melalui Penerapan Contextual Teaching and Learning (CTL) pada Kelas IV SDN 20 Battang”.

\section{B. Metode Penelitian}

Penelitian ini merupakan penelitian tindakan kelas (Classroom Action Research). I GAK Wardhani, dkk (2007:13) penelitian tindakan kelas yaitu suatu tindakan penelitian yang dilakukan oleh guru di dalam kelasnya sendiri melalui refleksi diri, dengan tujuan untuk memperbaiki kinerjanya sebagai guru sehingga hasil belajar siswa meningkat.

Penelitian tindakan kelas merupakan penelitian yang reflektif. Kegiatan penelitian berangkat dari permasalahan yang dihadapi oleh guru dalam proses belajar mengajar, kemudian direfleksikan alternatif pemecahan masalahnya dan ditindaklanjuti dengan tindakan-tindakan terencana dan terukur. Oleh karena itu, penelitian tindakan kelas membutuhkan kerjasama antara peneliti, guru, siswa dan staf sekolah lainnya untuk menciptakan suatu kinerja sekolah yang lebih baik. Penelitian ini berpola kolaboratif, di mana penelitian ini melibatkan peneliti sendiri sebagai guru model sekaligus sebagai instrumen utama observer yang bertindak sebagai pengamat.

Model penelitian tindakan kelas yang digunakan adalah model PTK dari Kemmis dan Taggart di mana model tersebut terkenal dengan sebutan model spiral. Alur penelitian tindakan kelas ini, dideskripsikan pada gambar dibawah ini: 


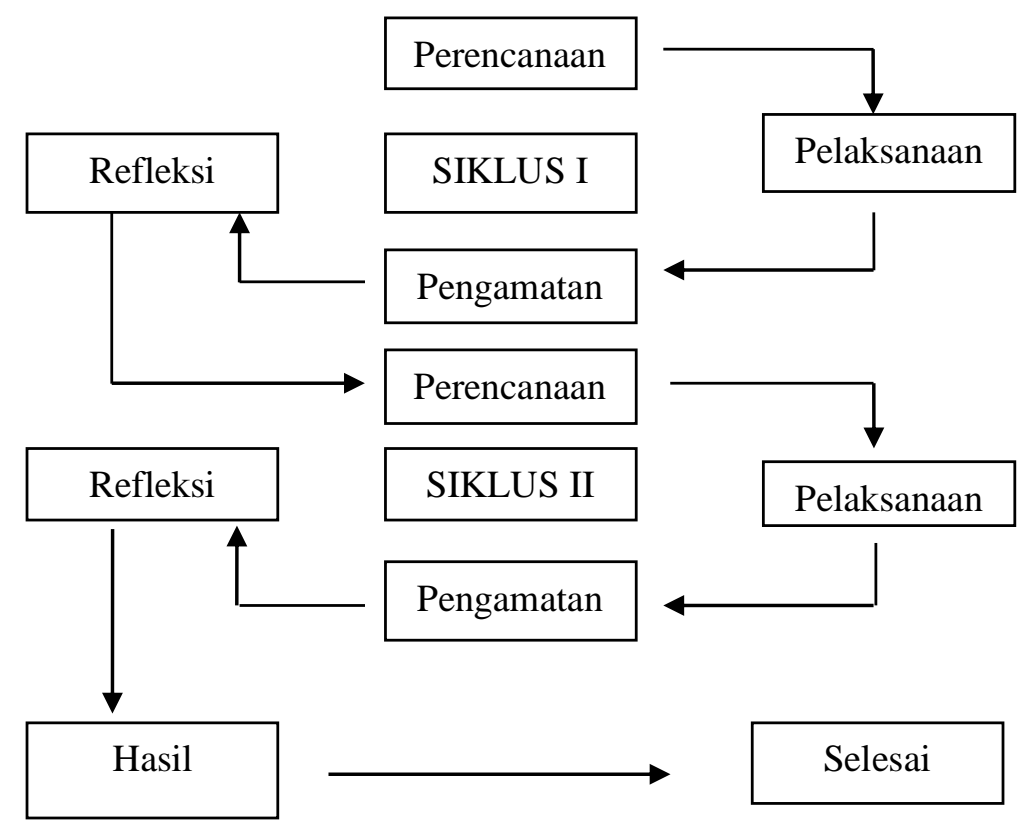

Gambar 1: Desain penelitian tindakan kelas (Kemmis dan Taggar)

Berdasarkan gambar di atas, tampak bahwa di dalamnya terdiri dari tiga perangkat komponen yang dapat dikatakan sebagai siklus, sedangkan dalam pelaksanaannya jumlah siklus sangat bergantung pada permasalahan yang akan diselesaikan. Apabila dua siklus yang dilaksanakan belum dapat mengatasi masalah, maka akan dilakukan tindakan perbaikan pada siklus selanjutnya. Dalam penelitian tindakan kelas ini penulis melaksanakan model PTK Kemmis dan Taggar dengan dua siklus.

\section{Hasil dan Pembahasan}

Penelitian ini dilakukan di SD Negeri 20 Battang. Sebelum melakukan penelitian, peneliti melakukan persiapan-persiapan yang dibutuhkan dalam penelitian. Persiapan penelitian meliputi wawancara dan observasi kelas. Berikut merupakan tabel tentang hasil pelaksanaan penelitian secara umum:

Tabel 1. Statistik deskriptif hasil belajar siswa Kelas IV SDN 20 Battang

\begin{tabular}{lccc}
\hline \multirow{2}{*}{\multicolumn{1}{c}{ Statistik }} & \multicolumn{3}{c}{ Nilai Statistik } \\
\cline { 2 - 4 } & Pretest & Siklus 1 & Siklus 2 \\
\hline Jumlah subjek & 14 & 14 & 14 \\
Nilai Ideal & 100 & 100 & 100 \\
Nilai Tertinggi & 90 & 90 & 100 \\
Nilai Terendah & 20 & 40 & 60 \\
Rentang Nilai & 70 & 50 & 40 \\
Nilai Rata-rata & 51,79 & 64,29 & 83,57 \\
Varian & 402,34 & 226,37 & 209,34 \\
Standar deviasi & 20,06 & 15,05 & 14,47 \\
\hline
\end{tabular}


Sumber: data primer (2018)

Jika keseluruhan nilai yang diperoleh peserta didik dikategorikan dalam skala lima, maka distribusi frekuensi dan persentase hasil belajar siswa pada saat pretest dapat dilihat pada tabel di bawah ini:

Tabel 2. Distribusi frekuensi dan persentase pretest siswa Kelas IV SDN 20 Battang.

\begin{tabular}{|c|c|c|c|c|}
\hline No. & Rentang Nilai & Kategori & Frekuensi & Persentase $(\%)$ \\
\hline 1. & $0-54$ & Sangat rendah & 7 & 50 \\
\hline 2. & $55-64$ & Rendah & 2 & 14,29 \\
\hline 3. & $65-79$ & Sedang & 4 & 28,57 \\
\hline 4. & $80-89$ & Tinggi & 0 & 0 \\
\hline 5. & $90-100$ & Sangat Tinggi & 1 & 7,14 \\
\hline \multicolumn{3}{|c|}{ Jumlah } & 14 & 100 \\
\hline
\end{tabular}

Berdasarkan tabel di atas diperoleh informasi sebanyak 7 orang siswa berada pada kategori sangat rendah dengan persentase 50\%, 2 orang atau 14,29\% siswa berada pada kategori rendah, 4 orang atau 28,57\% siswa berada pada kategori sedang dan 1 orang siswa berada pada kategori sangat tinggi atau sebanyak 7,14\%.

Tabel 3. Distribusi frekuensi hasil belajar siswa SDN 20 Battang pada siklus 1.

\begin{tabular}{ccccc}
\hline No. & Rentang Nilai & Kategori & Frekuensi & Persentase (\%) \\
\hline 1. & $0-54$ & Sangat rendah & 3 & 21,43 \\
2. & $55-64$ & Rendah & 5 & 35,71 \\
3. & $65-79$ & Sedang & 2 & 14,28 \\
4. & $80-89$ & Tinggi & 3 & 21,43 \\
5. & $90-100$ & Sangat tinggi & 1 & 7,14 \\
\hline \multicolumn{7}{r}{ Jumlah } & & 14 & 100 \\
\hline
\end{tabular}

Dari tabel di atas terlihat bahwa $21,43 \%$ atau 3 orang siswa berada pada kategori sangat rendah, $35,71 \%$ atau 5 orang siswa berada pada kategori rendah, $14,28 \%$ atau 2 orang siswa berada pada kategori sedang, 3 orang atau 21,43\% siswa berada pada kategori tinggi dan 1 orang siswa berada pada kategori sangat tinggi dengan persentase yang masih sama dengan pretest sebesar 7,14\%. Juga melalui tabel 3. Dapat ditarik sebuah kesimpulan bahwa pada dasarnya pengetahuan atau kognitif siswa terhadap pelajaran matematika masih sangat rendah sehingga diperlukan suatu perlakuan metode yang baru untuk meningkatkan hasil belajar siswa dalam pelajaran matematika. 
Tabel 4. Distribusi frekuensi hasil belajar siswa SDN 20 Battang pada siklus 2

\begin{tabular}{|c|c|c|c|c|}
\hline No. & Rentang Nilai & Kategori & Frekuensi & Persentase (\%) \\
\hline 1. & $0-54$ & Sangat rendah & 0 & 0 \\
\hline 2. & $55-64$ & Rendah & 1 & 7,14 \\
\hline 3. & $65-79$ & Sedang & 5 & 35,71 \\
\hline 4. & $80-89$ & Tinggi & 0 & 0 \\
\hline 5. & $90-100$ & Sangat tinggi & 8 & 57,14 \\
\hline
\end{tabular}

Berdasarkan tabel tersebut terlihat tidak ada lagi siswa yang berada pada kategori sangat rendah. Namun masih terdapat 1 orang berada pada kategori rendah sebanyak 7,14\%, 5 orang siswa berada pada kategori sedang sebesar $35,71 \%$, dan $57,14 \%$ atau 8 siswa berada pada kategori sangat tinggi. pada Tabel. 4 pun dapat ditarik kesimpulan bahwa pada siklus II telah mengalami peningkatan yang sangat signifikan, sehingga penerapan Contextual Teaching and Learning (CTL) dalam pembelajaran dinilai sangat efektif.

Selanjutnya dari hasil belajar siswa diperoleh rata-rata nilai siswa yang digambarkan dalam tabel sebagai berikut:

Tabel 5. Rekapitulasi hasil belajar siswa

\begin{tabular}{lccccc}
\hline \multirow{1}{*}{ Hasil Tes Siswa } & \multicolumn{3}{c}{ Nilai } & \multirow{2}{*}{$\begin{array}{c}\text { N- } \\
\text { Gain 1 }\end{array}$} & $\begin{array}{c}\text { N- } \\
\text { Gain 2 }\end{array}$ \\
\cline { 2 - 4 } & $\begin{array}{l}\text { Sebelum } \\
\text { tindakan }\end{array}$ & Siklus I & Siklus II & & \\
\hline Nilai Tertinggi & 90 & 90 & 100 & 0,00 & 1 \\
Nilai Terendah & 20 & 40 & 60 & 0,25 & 0,33 \\
Nilai Rata-rata & 51,78 & 64,29 & 83,57 & 0,26 & 0,54 \\
Siswa tuntas belajar $(\geq 68)$ & $28,57 \%$ & $42,86 \%$ & $92,86 \%$ & & \\
\hline
\end{tabular}

Indikator ketercapaian hasil belajar siswa dalam penelitian ini adalah jika rata-rata nilai hasil tes siswa telah mencapai nilai KKM > 68 maka penelitian dihentikan. Dilihat dari tabel di atas bahwa rata-rata nilai tes sebelum tindakan sebesar 51,78, siklus I sebesar 64,29 dan siklus II sebesar 83,57. Hal tersebut berartihasil belajar siswa selama dua siklus ini mengalami peningkatan yaitu dari sebelum tindakan ke siklus I sebesar $24,16 \%$ dan dari siklus I ke siklus II sebesar 44,98\%. Hal ini terlihat pada gambar di bawah ini: 


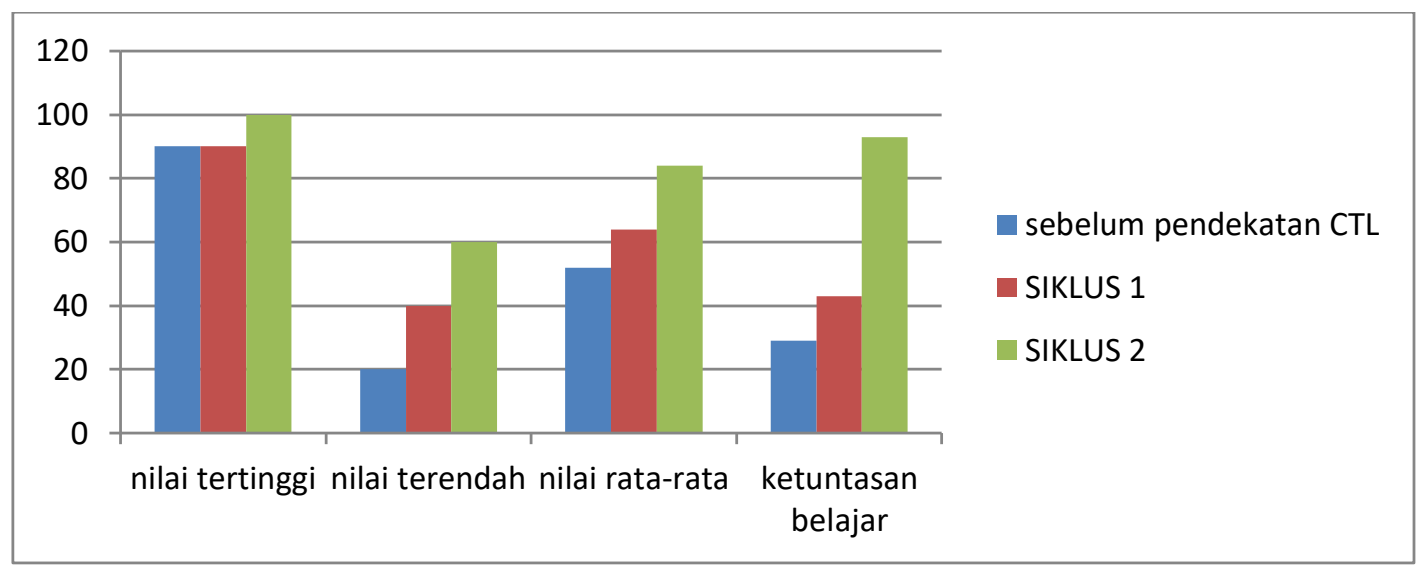

Gambar 2. Hasil belajar siswa

Berdasarkan tabel 12 diperoleh informasi sebanyak 7 orang siswa berada pada kategori sangat rendah dengan persentase 50\%, 2 orang atau 14,29\% siswa berada pada kategori rendah, 4 orang atau 28,57\% siswa berada pada kategori sedang dan 1 orang siswa berada pada kategori sangat tinggi atau sebanyak $7,14 \%$. Indikator ketercapaian hasil belajar siswa dalam penelitian ini adalah jika rata-rata nilai hasil tes siswa telah mencapai nilai KKM > 68 maka penelitian dihentikan. Dilihat dari tabel di atas bahwa rata-rata nilai tes sebelum tindakan sebesar 51,78, siklus I sebesar 64,29 dan siklus II sebesar 83,57. Hal tersebut berarti hasil belajar siswa selama dua siklus ini mengalami peningkatan yaitu dari sebelum tindakan ke siklus I sebesar 24,16\% dan dari siklus I ke siklus II sebesar 44,98\%. Pada siklus I dinyatakan bahwa ketuntasan belajar siswa secara maksimal belum tercapai. Hal ini disebabkan masih ada beberapa siswa yang belum mampu menerapkan media pembelajaran secara maksimal. Implikasi dari hal tersebut tentunya akan berdampak pada kuarangnya motivasi siswa dan keaktifan siswa dalam memberikan perhatian pada materi yang dijelaskan oleh guru pada saat pembelajaran, dan ditambah lagi oleh factor psikologi siswa yang masih malu dan takut untuk bertanya, padahal jika diajukan soal masih ada saja yang tidak mengerti. Kemudian dalam pembentukan kelompok masih ada saja siswa yang mengganggu kelompok lain serta kurangnya kerjasama di dalam kelompok yang telah dibentuk untuk bekerjasama mencari solusi dari soal atau masalah yang diajukan oleh guru.

Pada siklus II terjadi peningkatan pemahaman konsep yang luar biasa sehingga menghasilkan prestasi yang memuaskan. Hal tersebut menunjukkan bahwa penggunaan alat peraga blok pecahan meningkatkan motivasi, pemahaman 
konsep dan hasil belajar siswa kelas IV SDN 20 Battang pada kompetensi dasar menjumlahkan dan mengurangkan pecahan, menghasilkan pemahaman yang sangat baik karena nilai rata-rata siswa 83,57 dan siswa yang pada saat siklus I masih ada yang kategori sangat kurang dan kurang dalam pemahaman konsepnya. Hasil penelitian menunjukkan adanya peningkatan hasil belajar siswa sejalan dengan penelitian Hutagaol (2013) yang menyatakan bahwa hasil belajar siswa yang mendapat pembelajaran dengan menggunakan pendekatan kontekstual, kemampuan representasi lebih baik daripada yang menggunakan pembelajaran konvensional.

\section{Kesimpulan}

Berdasarkan hasil penelitian dapat ditarik kesimpulan sebagai berikut:

1. Meningkatnya hasil belajar siswa yaitu terlihat pada nilai rata-rata sebelum pendekatan CTL dilakukan sebesar 51,78 dikategorikan sangat rendah. Kemudian setelah dilakukan pendekatan CTL, rata-rata hasil belajar siswa pada siklus I sebesar 64,29dan pada siklus II sebesar 83,57. Jadi, dapat dikatakan bahwa sudah termasuk kategori tinggi.

2. Setelah pendekatan CTL diterapkan, maka hasil belajar matematika siswa kelas IV SDN 20 Battang meningkat.

\section{Daftar Pustaka}

Depdiknas. 2003. Pendekatan Kontekstual (CTL). Depdikbud. Jakarta.

Dimyati dan Mudjiono. 2004. Belajar dan Pembelajaran. Jakarta: PT. Rineka Cipta.

Hutagaol. 2013. Pembelajaran Kontekstual untuk Meningkatkan Kemampuan Representasi Matematis Siswa Sekolah Menengah Pertama. Infinity Journal (Online), Vol 2 No:1. http://www.e-journal.stikipsiliwangi.ac.id.Diakses pada 24 Oktober 2017.

I.G.A.K Wardani. 2007. Penelitian Tindakan Kelas. Universitas Terbuka.

Jonson B. Elaine. 2009. Contextual Teaching \& Learning Menjadikan Kegiatan Belajar Mengajar Mengasyikkan dan Bermakna. Bandung : ML.

Maulida, L. 2014. Penerapan Pendekatan Contextual Teaching and Learning untuk Meningkatkan Aktivitas Belajar Matemarika di Kelas IV MIN 
Parung.(Online). Vol.1 No.1. http://scholar.google.co.id. Diakses pada 23 Agustus 2018.

Sardiman A.m. 2008. Interaksi dan Motivasi Belajar Mengajar. Jakarta: PT. RajaGrafindo Persada. 